УДК 371

DOI:

Вікторія Конопля, аспірант кафедри фізико-математичної освіти і інформатики Глухівського національного педагогічного університету імені Олександра Довженка

Наталія Кугай, кандидат педагогічних наук,

дочент кафедри фізико-математичної освіти і інформатики

Глухівського національного педагогічного університету імені Олександра Довженка

\title{
ПОРІВНЯЛЬНИЙ АНАЛІЗ ІНФОРМАТИЧНОЇ СКЛАДОВОЇ ПДГОТОВКИ МАЙБУТНІХ УЧИТЕЛІВ МАТЕМАТИКИ (На прИКЛаді поЛЬського педагогічного університету імені комісії національної освіти в Кракові)
}

У статті проаналізовано навчальний план Педагогічного університету імені Комісії національної освіти в Кракові підготовки студентів-математиків. 3'ясовано, які саме дисципліни інформатичного спрямування та в якому обсязі вивчаються. Складено порівняльну діаграму і таблицю інформатичної підготовки майбутніх учителів у Польщі за такими спеціальностями: "Математика (вчитель)", “Математика з інформатикою (вчитель)”, “Математика з англійською мовою (вчитель)”, “Математика та олігофренопедагогіка (вчитель)” та "Прикладна математика".

Ключові слова: підготовка майбутнього вчителя математики; предмети інформатичного спрямування; навчальний план; Польща.

Рис. 1. Табл. 1. Літ. 1.

Victoriya Konoplya, Postgraduate Student of the Physics and Mathematics Education and Informatics Department Hlukhiv Oleksander Dovzhenko National Pedagogical University

Nataliya Kuhai, Ph.D.(Pedagogy), Associate Professor of the Physics and Mathematics Education and Informatics Department Hlukhiv Oleksander Dovzhenko National Pedagogical University

\section{THE COMPARATIVE ANALYSIS OF INFORMATICS COMPONENT OF TRAINING OF FUTURE TEACHERS OF MATHEMATICS (Based on example of the polish pedagogical university named after the National Educational Comission in Krakov)}

Ukraine, integrateing into the world's information space, is aspiring to raise the level of information culture of citizens. Thus, the importance of forming the ICT-competence of teachers of all profiles, including mathematics, is growing, which is not only a guarantee of the successful formation of the information culture of the younger generation, but also a key to the introduction of new information technologies into various fields of society.

The issue of the informatics component of training of mathematics teachers remains insufficiently developed, in particular, in terms of scientific study and implementation of foreign countries experience, especially the neighboring states, including Poland.

The purpose of the article. The analysis of the informatics component of training of future mathematics teachers in higher education institutions in Poland, in particular at the Pedagogical University named after the National Education Commission in Krakow.

The article analyzes the curriculum of the teaching staff in Pedagogical University named after the National Education Commission in Krakow for the students of mathematics. It is found out which disciplines of the informative direction and in what amount are studied. A comparative diagram and a table of informational training of future mathematics teachers in Poland are made.

After the analysis of the training curricula for students of mathematical specialties it was found out that the computer science component occupies an important place in the training of future specialists. For students of specialties "Mathematics with Informatics (teacher)" and "Applied Mathematics" it is 33 - 38 ECTS credits, that is $18-21 \%$ of the total load, for students of the specialty "Mathematics (teacher)" it is $18-23$ credits ECTS, that is 10-13\% of the total load, for students of specialties "Mathematics with English Language (teacher)", "Mathematics and Oligophrenic Pedagogy (teacher)" is much more less.

Keywords: preparation of the future teacher of mathematics; subjects of the informatic component, curriculum; Poland. 


\section{ПОРІВНЯЛЬНИЙ АНАЛІЗ ІНФОРМАТИЧНОЇ СКЛАДОВОЇ ПІДГОТОВКИ МАЙБУТНІХ УЧИТЕЛІВ МАТЕМАТИКИ}

(на прикладі польського педагогічного університету імені комісії національної освіти в Кракові)

майбутніх учителів, у тому числі вчителів математики. Сучасна школа потребує фахівців, здатних сприяти розвиткові самостійної i відповідальної особистості, вихованню творчої індивідуальності. Сьогодні неможливо розв'язувати проблеми, що виникають у конструюванні й організації освітнього процесу звичними способами, спираючись тільки на власний досвід; необхідно враховувати соціальні й культурні потреби підростаючого покоління, інновації та міжнародний досвід.

Україна, інтегруючись у світовий інформаційний простір, прагне підвищувати рівень інформаційної культури своїх громадян. У зв'язку з цим зростає важливість формування ІКТ-компетентності вчителів всіх профілів, у тому числі і математики, що є не тільки гарантією успішного формування інформаційної культури молодого покоління, а й запорукою впровадження нових інформаційних технологій у різні сфери діяльності суспільства.

Аналіз основних досліджень і публікацій. На сучасному етапі окремі аспекти проблеми підготовки майбутніх учителів математики в Україні досліджують відомі математики, педагоги і методисти: І. Акуленко, О. Матяш, В. Бевз, М. Бурда, Н. Вірченко, М. Жалдак, Г. Михалін, В. Моторіна, О. Скафа, С. Раков, О. Співаковський, Н.Тарасенкова, В. Швець, М. Шкіль та ін.

Вивченням питання інформатичної підготовки вчителів математики в України займаються:В. Биков, Ю. Горошко, М. Жалдак, В. Жукова, I. Кондратенко, Т. Крамаренко, С. Раков, Ю. Рамський, О. Співаковський, Ю. Триус та інші.

До освітньої практики Польщі зверталися дослідники:Н. Кугай $[1 ; 2 ; 3 ; 4]$,А. Каплун, С. Коваленко, I. Ковчина, В. Ханенко, А. Василюк, С. Деркач, О. Кучай та ін., але їхні дослідження, або не стосуються проблеми підготовки вчителів математики, або висвітлюють ії з іншого боку.

Питання інформатичної складової підготовки вчителів математики залишається недостатньо розробленим, зокрема в плані наукового вивчення i впровадження досвіду зарубіжних країн, передусім - сусідніх держав, у томучислі Польщі.

Мета статті. Проаналізувати інформатичну складову підготовки майбутніх учителів математики увищих навчальних закладах Польщі, зокрема в Педагогічному університету імені Комісії національної освіти в Кракові.

Виклад основного матеріалу. Підготовка студентів-математиків (бакалаврів) у Педагогічному університеті імені Комісії національної освіти в Кракові [5] триває три роки
(6 семестрів) і здійснюється за п'ятьма спеціальностями: “Математика (вчитель)”, “Математика 3 інформатикою (вчитель)”, “Математика 3 англійською мовою (вчитель)", “Математика та олігофренопедагогіка (вчитель)" та "Прикладна математика".

Для кожної спеціальності розроблено окремий навчальний план, який складається 3 обов'язкових дисциплін, курсів за вибором, спеціалізованих модулів за вибором та інших видів діяльності.

Обов'язкові дисципліни однакові для студентів математиків всіх п’яти спеціальностей. Курси за вибором представлені вивченням однієї 3 іноземних мов (англійська, французька, німецька, російська) або іншими дисциплінами- “Фізична культура" (на вибір є багато курсів), “Вивчення мови математичних текстів”, “Вступ до функціонального аналізу” та багато інших. Інші види діяльності передбачають заняття, на які відводяться по декілька годин і вивчаються в 1 2 семестрах: в першому семестрі студенти проходять “Тренінг з охорони праці” (4 години) та "Навчання в технології користування бібліотеками" (2 години), у 2-му семестрі “Побудова власного наукового шляхуі професійної кар'єри” (2 години). Починаючи з 3-го семестру вводяться спеціалізовані модулі за вибором, які встановлені окремо для кожної спеціалізації. На них відводиться значна частина навантаження по 15 кредитів ECTS в 3-5 семестрах і 13 кредитів ECTS в 6-му семестрі. В кінці 6-го семестру студенти захищають дипломну роботу.

Обов'язкові дисципліни передбачають вивчення незначної кількості дисциплін інформатичного спрямування, а саме: у 2-му семестрі вивчаються дисципліни "Математичні пакети” в обсязі 3 кредитів ECTS та “Інформатика" - 5 кредитів ECTS.

Серед курсів за вибором в 4-му семестрі $\epsilon$ "Програмування VBA у MS Office" в обсязі 2 кредитів ECTS та "Електронні таблиці Excel в імовірнісних додатках" - 2 кредитів ECTS, в 6му семестрі - “Функціональне програмування” в обсязі 1 кредиту ECTS.

Розглянемо детально спеціалізований модульний план для студентів спеціальності “Математика 3 інформатикою (вчитель)". В 3-му семестрі вивчаються такі курси інформатичного спрямування: “Теоретичні основи інформатики" в обсязі 3 кредитів ECTS, “Електронні таблиці Excel $з$ елементами VBA" - 2 кредити ECTS та “Розробка веб-сайту” - 2 кредити ECTS. В 4-му семестрі: “Дидактика інформатики для початкової школи 1" - 2 кредити ECTS та “Об'єктно- 


\section{ПОРІВНЯЛЬНИЙ АНАЛІЗ ІНФОРМАТИЧНОЇ СКЛАДОВОЇ ПІДГОТОВКИ МАЙБУТНІХ УЧИТЕЛІВ МАТЕМАТИКИ}

(на прикладі польського педагогічного університету імені комісії національної освіти в Кракові)

орієнтоване програмування - 3 кредити ECTS. В 5-му семестрі: “Дидактика інформатики для початкової школи 2" - 2 кредити ECTS, "Реляційні бази даних" - 2 кредити ECTS, “Операційні системи” - 2 кредити ECTS, "Парадигма та методи програмування" - 1 кредит ECTS. В 6-му семестрі: “Комп’ютерні мережі”2 кредити ECTS, “Бази даних у веб-ресурсах” - 2 кредити ECTS, "Налаштування та управління системами CMS” - 2 кредити ECTS.

Отже, всього предмети інформатичного спрямування вивчаються 33 - 38 кредитів ECTS в залежності від вибору студентів. Це складає 18 $-21 \%$ від загального навантаження (180 кредитів).

Щоб підкреслити важливість інформатичної підготовки студентів спеціальності "Математика 3 інформатикою (вчитель)”, порівняємо їхній спеціалізований модульний план 3 планом підготовки студентів спеціальності "Прикладна математика". В 3-му семестрі вивчаються такі курси інформатичного спрямування: "Електронні таблиці Excel $з$ елементами VBA" - 2 кредити ECTS, "Розробка веб-сайту” - 2 кредити ECTS, "Математичне та комп'ютерне моделювання 1" 4 кредити ECTS. В 4-му семестрі: “Математичне та комп'ютерне моделювання 2" - 3 кредити ECTS, “Системи управління базами даних Access” - 2 кредити ECTS та “Об'єктно-орієнтоване програмування” - 3 кредити ECTS. В 5-му семестрі: "Реляційні бази даних" - 2 кредити ECTS, "Парадигма та методи програмування" 1 кредит ECTS. В 6-му семестрі: “Бази даних у веб-ресурсах" - 2 кредити ECTS, "Налаштування та управління системами CMS" - 2 кредити ECTS, “Програмування на Java" - 2 кредити ECTS.

Отже, всього предмети інформатичного спрямування вивчаються 33 - 38 кредитів ECTS в залежності від вибору студентів. Це складає 18 - $21 \%$ від загального навантаження студентів. Тобто, інформатична підготовка займає такий самий обсяг, як і для студентів спеціальності "Математика $з$ інформатикою (вчитель)".

Розглянемо детально спеціалізований модульний план для студентів спеціальності “Математика (вчитель)”. В 3-му семестрі вивчаються такі курси інформатичного спрямування: “Електронні таблиці Excel з елементами VBA" - 2 кредити ECTS та в курсах за вибором "Розробка веб-сайту" - 2 кредити ECTS. В 4-му семестрі: в курсах за вибором “Системи управління базами даних Access" - 2 кредити ECTS. В 5-му семестрі: в курсах за вибором “Програмування на C++"-2 кредити ECTS, "Інтерактивна дошка як засіб викладання математики" - 2 кредити ECTS (з яких вибрати можна лише 2 кредити ECTS). В 6-му семестрі: в курсах за вибором “Застосування Excel та мови R y статистичних дослідженнях”-2 кредити ЕСТS, “Бази даних у веб-ресурсах" - 2 кредити ECTS, "Налаштування та управління системами CMS" - 2 кредити ECTS, “Програмування на Јava” - 2 кредити ECTS (з яких вибрати можна лише 4 кредити ECTS).

Проведений аналіз інформатичної складової підготовки майбутніх учителів математики у Педагогічному університету імені Комісії національної освіти в Кракові відображено на рисунку 1 і таблиці 1 .

Отже, всього предмети інформатичного спрямування вивчаються 18 - 23 кредити ECTS в залежності від вибору студентів. При загальному навантаженні 180 кредитів ECTS за 3 роки навчання це складає $10-13 \%$.

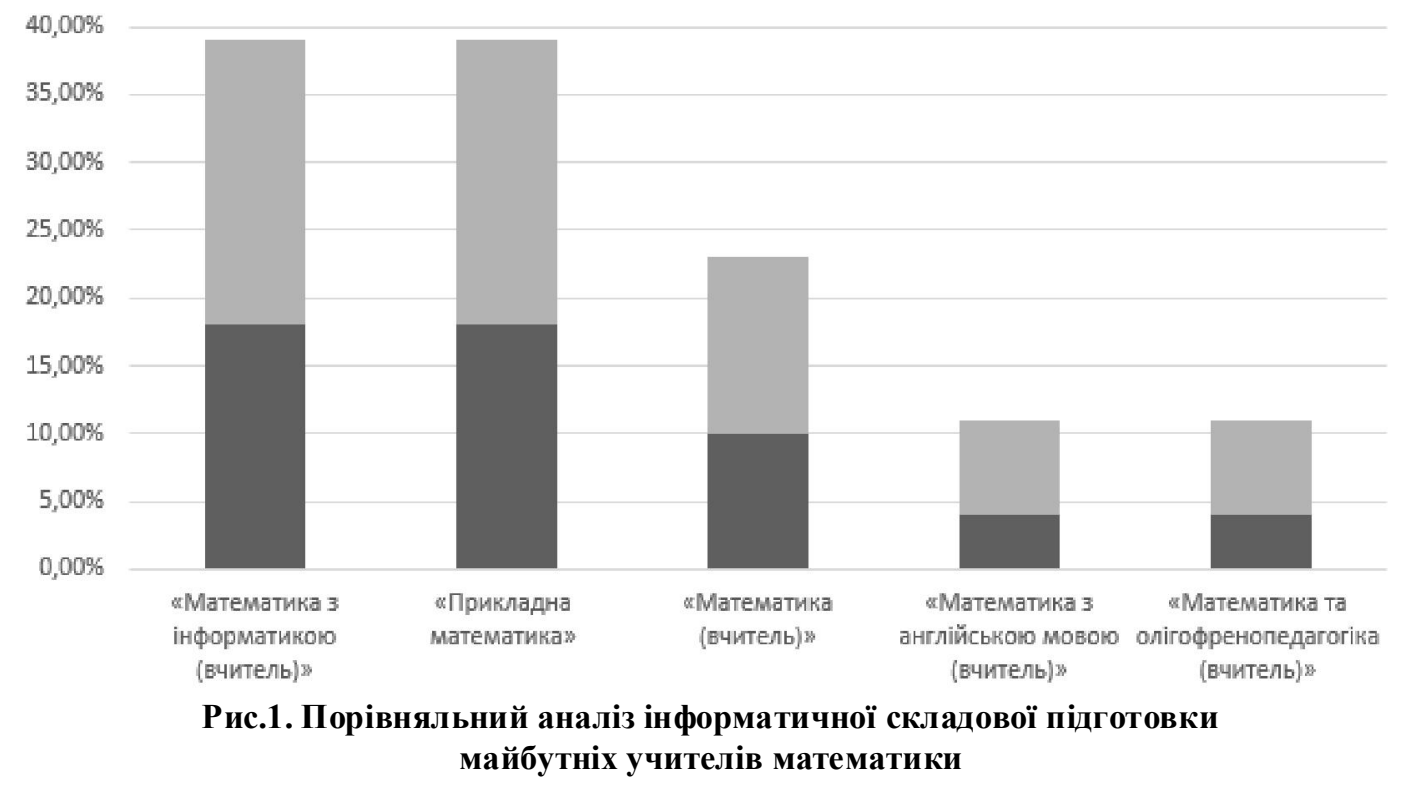




\section{ПОРІВНЯЛЬНИЙ АНАЛІЗ ІНФОРМАТИЧНОЇ СКЛАДОВОЇ ПІДГОТОВКИ МАЙБУТНІХ УЧИТЕЛІВ МАТЕМАТИКИ}

(на прикладі польського педагогічного університету імені комісії національної освіти в Кракові)

Таблиця 1.

Аналіз інформатичної складової підготовки майбутніх учителів математики

\begin{tabular}{|c|c|c|c|c|c|}
\hline $\begin{array}{l}\text { Навчальні } \\
\text { дисципліни } \\
\text { інформатичного } \\
\text { спрямування }\end{array}$ & $\begin{array}{l}\text { "Математика } \\
\text { (вчитель)" }\end{array}$ & $\begin{array}{l}\text { "Математика } 3 \\
\text { інформатикою } \\
\text { (вчитель)" }\end{array}$ & $\begin{array}{l}\text { "Математика } \\
3 \text { англійською } \\
\text { мовою } \\
\text { (вчитель)" }\end{array}$ & $\begin{array}{l}\text { "Математика } \\
\text { та } \\
\text { олігофренопе- } \\
\text { дагогіка } \\
\text { (вчитель)" }\end{array}$ & $\begin{array}{l}\text { "Прикладна } \\
\text { математика" }\end{array}$ \\
\hline \multicolumn{6}{|c|}{2 семестр } \\
\hline $\begin{array}{l}\text { “Математичні } \\
\text { пакети” (3 кредити } \\
\text { ECTS) }\end{array}$ & Обов'язкова & Обов’ язкова & Обов'язкова & Обов’ язкова & Обов'язкова \\
\hline $\begin{array}{l}\text { “Інформатика” (5 } \\
\text { кредитів ECTS) }\end{array}$ & Обов’язкова & Обов’ язкова & Обов’язкова & Обов’ язкова & Обов'язкова \\
\hline \multicolumn{6}{|c|}{3 семестр } \\
\hline $\begin{array}{l}\text { "Теоретичні } \\
\text { основи } \\
\text { інформатики" (3 } \\
\text { кредити ECTS) }\end{array}$ & $\begin{array}{l}\text { Не } \\
\text { передбачено }\end{array}$ & Обов’ язкова & $\begin{array}{l}\text { Не } \\
\text { передбачено }\end{array}$ & $\begin{array}{l}\mathrm{He} \\
\text { передбачено }\end{array}$ & $\begin{array}{l}\mathrm{He} \\
\text { передбачено }\end{array}$ \\
\hline $\begin{array}{l}\text { “Електронні } \\
\text { таблиці Excel з } \\
\text { елементами VBA” } \\
\text { (2 кредити ECTS) }\end{array}$ & Обов’язкова & Обов’ язкова & $\begin{array}{l}\text { Не } \\
\text { передбачено }\end{array}$ & $\begin{array}{l}\mathrm{He} \\
\text { передбачено }\end{array}$ & Обов'язкова \\
\hline $\begin{array}{l}\text { “Розробка веб- } \\
\text { сайту” (2 кредити } \\
\text { ECTS) }\end{array}$ & $\begin{array}{l}\text { В курсах за } \\
\text { вибором }\end{array}$ & Обов’ язкова & $\begin{array}{l}\text { Не } \\
\text { передбачено }\end{array}$ & $\begin{array}{l}\mathrm{He} \\
\text { передбачено }\end{array}$ & Обов'язкова \\
\hline $\begin{array}{l}\text { “Математичне та } \\
\text { комп’ютерне } \\
\text { моделювання 1” (4 } \\
\text { кредити ECTS) }\end{array}$ & $\begin{array}{l}\text { Не } \\
\text { передбачено }\end{array}$ & $\begin{array}{l}\text { Не } \\
\text { передбачено }\end{array}$ & $\begin{array}{l}\text { Не } \\
\text { передбачено }\end{array}$ & $\begin{array}{l}\text { Не } \\
\text { передбачено }\end{array}$ & Обов'язкова \\
\hline \multicolumn{6}{|c|}{4 семестр } \\
\hline $\begin{array}{l}\text { "Програмування } \\
\text { VBA у MS Office" } \\
\text { (2 кредити ECTS) }\end{array}$ & $\begin{array}{l}\text { В курсах за } \\
\text { вибором }\end{array}$ & $\begin{array}{l}\text { В курсах за } \\
\text { вибором }\end{array}$ & $\begin{array}{l}\text { В курсах за } \\
\text { вибором }\end{array}$ & $\begin{array}{l}\text { В курсах за } \\
\text { вибором }\end{array}$ & $\begin{array}{l}\text { В курсах за } \\
\text { вибором }\end{array}$ \\
\hline $\begin{array}{l}\text { “Електронні } \\
\text { таблиці Excel в } \\
\text { імовірнісних } \\
\text { додатках” (2 } \\
\text { кредити ECTS) }\end{array}$ & $\begin{array}{l}\text { В курсах за } \\
\text { вибором }\end{array}$ & $\begin{array}{l}\text { В курсах за } \\
\text { вибором }\end{array}$ & $\begin{array}{l}\text { В курсах за } \\
\text { вибором }\end{array}$ & $\begin{array}{l}\text { В курсах за } \\
\text { вибором }\end{array}$ & $\begin{array}{l}\text { В курсах за } \\
\text { вибором }\end{array}$ \\
\hline $\begin{array}{l}\text { “Дидактика } \\
\text { інформатики для } \\
\text { початкової школи } \\
1 \text { 1” (2 кредити } \\
\text { ECTS) }\end{array}$ & $\begin{array}{l}\text { Не } \\
\text { передбачено }\end{array}$ & Обов’ язкова & $\begin{array}{l}\mathrm{He} \\
\text { передбачено }\end{array}$ & $\begin{array}{l}\text { Не } \\
\text { передбачено }\end{array}$ & $\begin{array}{l}\text { Не } \\
\text { передбачено }\end{array}$ \\
\hline $\begin{array}{l}\text { “Об’єктно- } \\
\text { орієнтоване } \\
\text { програмування” (3 } \\
\text { кредити ECTS) }\end{array}$ & $\begin{array}{l}\text { Не } \\
\text { передбачено }\end{array}$ & Обов’ язкова & $\begin{array}{l}\text { Не } \\
\text { передбачено }\end{array}$ & $\begin{array}{l}\text { Не } \\
\text { передбачено }\end{array}$ & Обов'язкова \\
\hline $\begin{array}{l}\text { “Математичне та } \\
\text { комп’ютерне } \\
\text { моделювання 2” (3 } \\
\text { кредити ECTS) }\end{array}$ & $\begin{array}{l}\text { Не } \\
\text { передбачено }\end{array}$ & $\begin{array}{l}\text { Не } \\
\text { передбачено }\end{array}$ & $\begin{array}{l}\text { Не } \\
\text { передбачено }\end{array}$ & $\begin{array}{l}\text { Не } \\
\text { передбачено }\end{array}$ & Обов'язкова \\
\hline $\begin{array}{l}\text { “Системи } \\
\text { управління базами } \\
\text { даних Access” (2 } \\
\text { кредити ECTS) }\end{array}$ & $\begin{array}{l}\text { В курсах за } \\
\text { вибором }\end{array}$ & $\begin{array}{l}\text { Не } \\
\text { передбачено }\end{array}$ & $\begin{array}{l}\mathrm{He} \\
\text { передбачено }\end{array}$ & $\begin{array}{l}\text { Не } \\
\text { передбачено }\end{array}$ & Обов'язкова \\
\hline \multicolumn{6}{|c|}{5 семестр } \\
\hline $\begin{array}{l}\text { “Дидактика } \\
\text { інформатики для }\end{array}$ & $\begin{array}{l}\text { Не } \\
\text { передбачено }\end{array}$ & Обов’ язкова & $\begin{array}{l}\text { Не } \\
\text { передбачено }\end{array}$ & $\begin{array}{l}\text { Не } \\
\text { передбачено }\end{array}$ & $\begin{array}{l}\mathrm{He} \\
\text { передбачено }\end{array}$ \\
\hline
\end{tabular}

Молодь і ринок №5 (160), 2018 


\section{ПОРІВНЯЛЬНИЙ АНАЛІЗ ІНФОРМАТИЧНОЇ СКЛАДОВОЇ ПІДГОТОВКИ МАЙБУТНІХ \\ УЧИТЕЛІВ МАТЕМАТИКИ}

(на прикладі польського педагогічного університету імені комісії національної освіти в Кракові)

\begin{tabular}{|c|c|c|c|c|c|}
\hline \multicolumn{6}{|c|}{ Продовження таблиці 1.} \\
\hline \multicolumn{6}{|c|}{5 семестр } \\
\hline $\begin{array}{l}\text { початкової школи 2” (2 } \\
\text { кредити ECTS) }\end{array}$ & $\begin{array}{l}\text { Не } \\
\text { передбачено }\end{array}$ & Обов’ язкова & $\begin{array}{l}\mathrm{He} \\
\text { передбачено }\end{array}$ & $\begin{array}{l}\text { Не } \\
\text { передбачено }\end{array}$ & $\begin{array}{l}\mathrm{He} \\
\text { передбачено }\end{array}$ \\
\hline $\begin{array}{l}\text { “Реляційні бази даних” } \\
\text { (2 кредити ЕСТS) }\end{array}$ & $\begin{array}{l}\text { Не } \\
\text { передбачено }\end{array}$ & Обов’ язкова & $\begin{array}{l}\text { Не } \\
\text { передбачено }\end{array}$ & $\begin{array}{l}\text { Не } \\
\text { передбачено }\end{array}$ & Обов'язкова \\
\hline $\begin{array}{l}\text { "Операційні системи” } \\
\text { (2 кредити ЕСТS) }\end{array}$ & $\begin{array}{l}\text { Не } \\
\text { передбачено }\end{array}$ & Обов’ язкова & $\begin{array}{l}\mathrm{He} \\
\text { передбачено }\end{array}$ & $\begin{array}{l}\text { Не } \\
\text { передбачено }\end{array}$ & $\begin{array}{l}\mathrm{He} \\
\text { передбачено }\end{array}$ \\
\hline $\begin{array}{l}\text { “Парадигма та методи } \\
\text { програмування” (1 } \\
\text { кредит ECTS) }\end{array}$ & $\begin{array}{l}\text { Не } \\
\text { передбачено }\end{array}$ & Обов’ язкова & $\begin{array}{l}\text { Не } \\
\text { передбачено }\end{array}$ & $\begin{array}{l}\text { Не } \\
\text { передбачено }\end{array}$ & Обов'язкова \\
\hline $\begin{array}{l}\text { “Програмування на } \\
\text { C++” (2 кредити ECTS) }\end{array}$ & $\begin{array}{l}\text { В курсах за } \\
\text { вибором }\end{array}$ & $\begin{array}{l}\text { Не } \\
\text { передбачено }\end{array}$ & $\begin{array}{l}\mathrm{He} \\
\text { передбачено }\end{array}$ & $\begin{array}{l}\text { Не } \\
\text { передбачено }\end{array}$ & $\begin{array}{l}\text { Не } \\
\text { передбачено }\end{array}$ \\
\hline $\begin{array}{l}\text { “Інтерактивна дошка як } \\
\text { засіб викладання } \\
\text { математики” (2 кредити } \\
\text { ECTS) }\end{array}$ & $\begin{array}{l}\text { В курсах за } \\
\text { вибором }\end{array}$ & $\begin{array}{l}\mathrm{He} \\
\text { передбачено }\end{array}$ & $\begin{array}{l}\mathrm{He} \\
\text { передбачено }\end{array}$ & $\begin{array}{l}\mathrm{He} \\
\text { передбачено }\end{array}$ & $\begin{array}{l}\text { Не } \\
\text { передбачено }\end{array}$ \\
\hline \multicolumn{6}{|c|}{6 семестр } \\
\hline $\begin{array}{l}\text { “Функціональне } \\
\text { програмування” (1 } \\
\text { кредит ECTS) }\end{array}$ & $\begin{array}{l}\text { В курсах за } \\
\text { вибором }\end{array}$ & $\begin{array}{l}\text { В курсах за } \\
\text { вибором }\end{array}$ & $\begin{array}{l}\text { В курсах за } \\
\text { вибором }\end{array}$ & $\begin{array}{l}\text { В курсах за } \\
\text { вибором }\end{array}$ & $\begin{array}{l}\text { В курсах за } \\
\text { вибором }\end{array}$ \\
\hline $\begin{array}{l}\text { “Комп’ютерні мережі” } \\
\text { (2 кредити ЕCTS) }\end{array}$ & $\begin{array}{l}\text { Не } \\
\text { передбачено }\end{array}$ & Обов' язкова & $\begin{array}{l}\mathrm{He} \\
\text { передбачено }\end{array}$ & $\begin{array}{l}\mathrm{He} \\
\text { передбачено }\end{array}$ & $\begin{array}{l}\text { Не } \\
\text { передбачено }\end{array}$ \\
\hline $\begin{array}{l}\text { “Бази даних у веб- } \\
\text { ресурсах” (2 кредити } \\
\text { ECTS) }\end{array}$ & $\begin{array}{l}\text { В курсах за } \\
\text { вибором }\end{array}$ & Обов’ язкова & $\begin{array}{l}\mathrm{He} \\
\text { передбачено }\end{array}$ & $\begin{array}{l}\text { Не } \\
\text { передбачено }\end{array}$ & Обов'язкова \\
\hline $\begin{array}{l}\text { “Налаштування та } \\
\text { управління системами } \\
\text { CMS” ( } 2 \text { кредити } \\
\text { ECTS) }\end{array}$ & $\begin{array}{l}\text { В курсах за } \\
\text { вибором }\end{array}$ & Обов' язкова & $\begin{array}{l}\mathrm{He} \\
\text { передбачено }\end{array}$ & $\begin{array}{l}\mathrm{He} \\
\text { передбачено }\end{array}$ & Обов'язкова \\
\hline $\begin{array}{l}\text { “Програмування на } \\
\text { Java” (2 кредити ECTS) }\end{array}$ & $\begin{array}{l}\text { В курсах за } \\
\text { вибором }\end{array}$ & $\begin{array}{l}\mathrm{He} \\
\text { передбачено }\end{array}$ & $\begin{array}{l}\mathrm{He} \\
\text { передбачено }\end{array}$ & $\begin{array}{l}\mathrm{He} \\
\text { передбачено }\end{array}$ & Обов'язкова \\
\hline $\begin{array}{l}\text { “Застосування Excel та } \\
\text { мови R у статистичних } \\
\text { дослідженнях” (2 } \\
\text { кредити ECTS) }\end{array}$ & $\begin{array}{l}\text { В курсах за } \\
\text { вибором }\end{array}$ & $\begin{array}{l}\mathrm{He} \\
\text { передбачено }\end{array}$ & $\begin{array}{l}\mathrm{He} \\
\text { передбачено }\end{array}$ & $\begin{array}{l}\mathrm{He} \\
\text { передбачено }\end{array}$ & $\begin{array}{l}\text { Не } \\
\text { передбачено }\end{array}$ \\
\hline
\end{tabular}

У спеціалізованих модульних планах для студентів спеціальностей "Математика 3 англійською мовою (вчитель)”, “Математика та олігофренопедагогіка (вчитель)” дисциплін інформатичного спрямування не передбачено. Отже, всього предмети інформатичного спрямування студентами цих спеціальностей вивчаються 8 - 13 кредитів ECTS в залежності від вибору студентів, це складає $4-7 \%$ від загального навантаження.

Висновки. У результаті аналізу навчальних планів польського Педагогічного університету імені Комісії національної освіти в Кракові підготовки студентів математичних спеціальностей 3'ясували, що інформатична складова займає важливе місце у підготовці майбутніх спеціалістів: для студентів спеціальностей "Математика 3 інформатикою (вчитель)” і “Прикладна математика" складає 33 - 38 кредитів ECTS, тобто
$18-21 \%$ від загального навантаження, для студентів спеціальності "Математика (вчитель)" - 18 - 23 кредити ECTS, тобто 10 - 13\% від загального навантаження, для студентів спеціальностей "Математика з англійською мовою (вчитель)", “Математика та олігофренопедагогіка (вчитель)" значно менше.

Подальші перспективи дослідження: проаналізувати навчальні плани інших польських університетів підготовки студентів спеціальності “Математика (вчитель)" (бакалавр та магістр), проаналізувати окремо карту знань кожного курсу інформатичного спрямування.

\section{ЛІТЕРАТУРА}

1. Кугай Н.В. Порівняльний аналіз підготовки майбутніх учителів математики у Польщі та Україні. Український педагогічний журнал. 2015. № 2. C. 23-32. 


\section{ПОРІВНЯЛЬНИЙ АНАЛІЗ ІНФОРМАТИЧНОЇ СКЛАДОВОЇ ПІДГОТОВКИ МАЙБУТНІХ УЧИТЕЛІВ МАТЕМАТИКИ}

(на прикладі польського педагогічного університету імені комісії національної освіти в Кракові)

2. Кугай Н.В., Борисов С.М. Система навчання майбутніх учителів математики у Польщі та Україні (магістратура): спільне та відмінне. Научные труды SWorld. 2016. № 2 (43). С. 42-48.

3. Кугай Н.В. Методологічна складова підготовки майбутнього вчителя математики у Польщі та Болгарії. Матеріали міжнародної науково-методичної конференції Проблеми математичної освіти ПМО - 2017 (26-28 вересня 2017 р., м. Черкаси). Черкаси, 2017. С. 236-237.

4. Кугай Н.В. Методологічні знання майбутнього вчителя математики: монографія. Харків: ФОП Панов А.М., 2017. 336 с.

5. Сайт Педагогічного університету імені Комісії національної освіти в Кракові (інститут математики) [Електронній ресурс] - Режим доступу: http://matematyka.up.krakow.pl/ planprog.php (дата звернення 11.04.2018).

\section{REFERENCES}

1. Kuhai, N.V. (2015). Porivnialnyi analiz pidhotovky maibutnikh uchyteliv matematyky u Polshchi ta Ukraini. [Comparative analysis of the training of future mathematics teachers in Poland and Ukraine]. Ukrainskyi pedahohichnyi zhurnal, no. 2, pp. 23-32. [in Ukrainian].

2. Kuhai, N.V. \& Borysov, Ye.M. (2016). Cystema navchannia maibutnikh uchyteliv matematyky u
Polshchi ta Ukraini (mahistratura): spilne ta vidminne [The system of training future mathematics teachers in Poland and Ukraine (master's degree): joint and excellent]. Nauchnie trudi SWorld, no. 2 (43), pp. 42-48. [in Ukrainian].

3. Kuhai, N.V. (2017). Metodolohichna skladova pidhotovky maibutnoho vchytelia matematyky u Polshchi ta Bolharii [The methodological component of the preparation of the future teacher of mathematics in Poland and Bulgaria]. Materialy mizhnarodnoi naukovo-metodychnoi konferentsii Problemy matematychnoi osvity PMO - 2017 (26-28 veresnia 2017 r., m. Cherkasy).- Proceedings of the International Scientific and Methodical Conference: The Problems of mathematical Education PME-2017 (26-28th September 2017, Cherkasy). (pp. 236-237), Cherkasy. [in Ukrainian].

4. Kuhai, N.V. (2017). Metodolohichni znannia maibutnoho vchytelia matematyky [Methodological knowledge of the future teacher of mathematics]. Kharkiv: FOP Panov A.M., 336 p. [in Ukrainian].

5. Sait Pedahohichnoho universytetu imeni Komisii natsionalnoi osvity $\mathrm{v}$ Krakovi (instytut matematyky)[Website of the Pedagogical University named after the National Education Commission in Krakow (Institute of Mathematics)]. [Electronnic resource]. Available at: http://matematyka.up.krakow.pl/ planprog.php (accessed 11 April 2018). [in Polish].

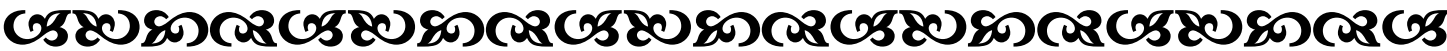

"Я̆ не виитель. Я тільки людина, яқа подорожує разом з тобою. Коли ти питаєи, қуди итти, я вқазую шлах попереду тебе і мене".

ФжорджБернард Шоу

ірландський драматуре і публіиист

"Кожна людина має свій горизонт. Коли він звужується $і$ стає нескінченно малим, то перетворюється на точку. ТТоді людина қаже: "Ie моя точқа зору".

Фавид Тілберт

німещький математик

"Якщо ви досягли вершини - піднімайтесь вище”.

Китайська мудрість

"Дамати стереотипи й пробиватися қрізь упередження - справа неймовірно сқладна, але ще й ббантастично приємна".

Dжаред Яето

американський актор

\section{G58080}

